\title{
Seasonal fluctuations of the nematode communities in a hop garden soil
}

\author{
M. RENČO, M. LIŠKOVÁ, A. ČEREVKOVÁ
}

Parasitological Institute of the Slovak Academy of Sciences, Hlinkova 3, 040 01, Košice, Slovak Republic, E-mail:renco@saske.sk

\begin{abstract}
Summary
A study on the seasonal fluctuation of nematode population was conducted during three vegetation periods (2005 2007), at 20 and $40 \mathrm{~cm}$ soil depth, from May to October, in a hop garden at Nemšová (Slovak Republic). The seasonal fluctuation of the nematode population was related to temperature and rainfall. At $20 \mathrm{~cm}$ soil depth of each year, the largest nematode population was recorded in July, and the smallest from July to October. At $40 \mathrm{~cm}$ soil depth, nematode abundance was not significantly different between the years 2006 and 2007. In general, at the same depth, a decrease of nematode abundance was observed from May to October. The soil nematode community was rich in bacteriovorous nematodes, especially in the top $20 \mathrm{~cm}$ soil. The genus Rhabditis was the eudominant taxon at both soil depths. This genus with the genera Cephalobus, Heterodera, Merlinius and Aglenchus represented the $50 \%$ of the total nematode population at $20 \mathrm{~cm}$ soil depth and with the genera Cephalobus, Helicotylenchus, Heterodera and Merlinius represented the $52 \%$ of total nematodes abundance at $40 \mathrm{~cm}$ depth.
\end{abstract}

Keywords: nematode community; seasonal fluctuation; trophic groups; hop garden; Slovak Republic

\section{Introduction}

Earlier investigations on nematodes in the hop gardens throughout the world were focused mostly on the cyst nematode Heterodera humuli. However, apart from information on $H$. humuli and some other plant parasitic nematodes species (Hay \& Pethybridge, 2003), knowledge of nematode communities in hop gardens is scarce.

The seasonal or temporal dynamic of occurrence of soil nematodes has been documented previously in several ecosystems e.g. forest (Sohlenius et al., 1987), sugar beet, cereals and lucerne (Renčo 2002), Ambrosia trifida and Chenopodium serotinum (Liang et al., 2007). Neher et al.
(2004) stated that fluctuation of nematodes during vegetation is influenced by several biotic and abiotic factors such as temperature, annual rainfall, type of soil and plants, organic substances, microflora and management practices. As reported by Bakonyi and Nagy (2000), temperature is the main factor influencing nematode diversity although the nematode abundance is predominantly affected by the soil moisture content.

In Slovakia the structure of nematode communities in hop gardens was studied only during a single season (2004) (Lišková \& Renčo, 2007), whereas information on the seasonal fluctuation of nematodes in a longer period is lacking. Such information would contribute to a better understanding of potential nematode problems and consequently, the adoption of appropriate measures to control phytoparasitic nematodes. Therefore, the objective of this investigation was to obtain information on the nematode population seasonal fluctuations in established hop gardens, and to determine the principal environmental factors affecting nematode population changes in a very important hop growing area of Slovakia.

\section{Materials and methods}

The study was undertaken in a hop garden at Nemšová in western region of Slovakia situated in a warm area with temperate and moderately humid winter. The locality is characterized by deep, permeable, clay sandy or sandy clay soils, soil type Luvisol or Fluvisol, with pH $6.6-7.8$. The locality is at an elevation of $181 \mathrm{~m} \mathrm{a}$. s. 1., characterized by annual isotherms during the years 2005-2007 of $9.4-$ $10.7^{\circ} \mathrm{C}$ and with annual rainfall of $580-760 \mathrm{~mm}$, while during the vegetation period (May - October) temperature was in the range $16.5-17.1^{\circ} \mathrm{C}$ and rainfall in the range $195-370 \mathrm{~mm}$. The studied hop garden was 30 years old and it was fertilized every year with $50-70 \mathrm{t} / \mathrm{ha}$ of cattle manure. 
Table 1. Dominance of nematode genera at each monthly sampling at $20 \mathrm{~cm}$ depth

\begin{tabular}{|c|c|c|c|c|c|c|c|c|}
\hline \multirow[t]{2}{*}{ Genus } & \multirow[t]{2}{*}{ TG } & \multicolumn{7}{|c|}{ Dominance \% $(n=3)$} \\
\hline & & $\mathbf{V}$ & VI & $\begin{array}{l}\text { VII } \\
\end{array}$ & VIII & IX & $\mathbf{X}$ & Total \\
\hline Acrobeles & $\mathrm{BF}$ & 0.04 & 0.03 & - & 0.14 & 0.21 & - & 0.08 \\
\hline Alaimus & $\mathrm{BF}$ & 1.44 & 1.37 & 1.27 & 0.42 & 0.90 & 0.72 & 1.08 \\
\hline Amphidelus & $\mathrm{BF}$ & 0.10 & - & 0.02 & 0.33 & - & - & 0.10 \\
\hline Aulolaimus & $\mathrm{BF}$ & - & 0.18 & - & 0.20 & 0.07 & - & 0.07 \\
\hline Cephalobus & $\mathrm{BF}$ & 4.16 & 5.04 & 7.54 & 9.04 & 12.13 & 10.91 & 7.67 \\
\hline Eucephalobus & $\mathrm{BF}$ & 3.20 & 2.95 & 1.24 & 1.95 & 2.33 & 4.25 & 2.51 \\
\hline Eumohohystera & $\mathrm{BF}$ & - & 0.23 & 0.16 & 0.31 & 0.14 & - & 0.18 \\
\hline Chiloplacus & $\mathrm{BF}$ & 3.26 & 3.57 & 2.48 & 3.32 & 4.24 & 2.74 & 3.17 \\
\hline Panagrolaimus & $\mathrm{BF}$ & 0.88 & 1.16 & 0.57 & 1.90 & 1.25 & 1.70 & 1.14 \\
\hline Plectus & $\mathrm{BF}$ & 1.03 & 0.94 & 1.18 & 2.18 & 1.81 & 2.01 & 1.37 \\
\hline Rhabditis & $\mathrm{BF}$ & 29.52 & 24.93 & 39.22 & 31.61 & 26.34 & 33.05 & 31.63 \\
\hline Aphelenchoides & $\mathrm{FF}$ & 0.88 & 1.11 & 1.08 & 0.95 & 0.87 & 0.85 & 0.97 \\
\hline Aphelenchus & $\mathrm{FF}$ & 4.00 & 3.10 & 4.26 & 3.07 & 2.40 & 3.52 & 3.54 \\
\hline Diphtherophora & $\mathrm{FF}$ & 0.02 & 0.03 & - & 0.11 & 0.03 & 0.09 & 0.04 \\
\hline Ditylenchus & $\mathrm{FF}$ & 0.16 & 0.10 & 0.16 & 0.47 & 0.31 & 0.16 & 0.21 \\
\hline Nothotylenchus & $\mathrm{FF}$ & 0.82 & 1.40 & 1.10 & 1.98 & 1.67 & 0.63 & 1.22 \\
\hline Seinura & $\mathrm{FF}$ & 0.31 & - & 0.25 & - & 0.52 & 0.25 & 0.28 \\
\hline Bitylenchus & PP & 1.95 & 2.17 & 0.65 & 1.42 & 1.77 & 1.23 & 1.45 \\
\hline Helicotylenchus & $\mathrm{PP}$ & 7.47 & 7.03 & 4.25 & 2.54 & 3.82 & 2.64 & 4.82 \\
\hline Heterodera & PP & 10.36 & 12.46 & 8.45 & 6.22 & 2.57 & 3.30 & 7.78 \\
\hline Merlinius & PP & 8.76 & 5.35 & 2.86 & 5.64 & 6.53 & 4.87 & 5.51 \\
\hline Paratylenchus & PP & 2.38 & 1.47 & 2.21 & 0.39 & 1.49 & 2.14 & 1.77 \\
\hline Pratylenchus & PP & 1.37 & 1.22 & 1.77 & 0.72 & 2.60 & 1.07 & 1.48 \\
\hline Tylenchorhynchus & $\mathrm{PP}$ & 0.60 & 0.88 & 0.21 & 0.47 & 1.09 & 0.47 & 0.51 \\
\hline Aglenchus & RFF & 3.43 & 4.63 & 5.52 & 5.13 & 6.15 & 6.48 & 5.11 \\
\hline Boleodorus & RFF & 1.70 & 1.27 & 1.86 & 0.98 & 1.88 & 0.75 & 1.46 \\
\hline Filenchus & RFF & 0.35 & 0.49 & 0.51 & 0.86 & 0.35 & 0.44 & 0.49 \\
\hline Tylenchus & RFF & 3.20 & 4.97 & 2.18 & 2.26 & 3.30 & 2.23 & 2.96 \\
\hline Campydora & $\mathrm{P}$ & 0.02 & 0.05 & - & 0.31 & 0.45 & - & 0.12 \\
\hline Clarkus & $\mathrm{P}$ & 0.33 & 0.59 & 0.37 & 0.70 & 0.28 & 0.41 & 0.44 \\
\hline Mononchus & $\mathrm{P}$ & 0.37 & 0.52 & 0.76 & 0.31 & 1.01 & 1.64 & 0.72 \\
\hline Mylonchulus & $\mathrm{P}$ & 0.33 & 0.80 & 0.59 & 0.89 & 1.18 & 1.16 & 0.76 \\
\hline Nygolaimus & $\mathrm{P}$ & - & 0.05 & - & 0.06 & 0.10 & - & 0.03 \\
\hline Tripyla & $\mathrm{P}$ & 0.04 & 0.08 & 0.10 & 0.14 & - & 0.06 & 0.13 \\
\hline Aporcelaimellus & $\mathrm{O}$ & 2.42 & 4.16 & 2.10 & 5.75 & 4.41 & 4.65 & 3.57 \\
\hline Axonchium & $\mathrm{O}$ & 0.18 & 0.23 & 0.11 & 0.17 & 0.45 & 0.13 & 0.19 \\
\hline Dorylaimoides & $\mathrm{O}$ & - & 0.13 & 0.08 & 0.06 & 0.14 & - & 0.06 \\
\hline Ecumenicus & $\mathrm{O}$ & 0.41 & 1.14 & 0.89 & 1.34 & 0.66 & 1.04 & 0.89 \\
\hline Eudorylaimus & $\mathrm{O}$ & 2.52 & 3.03 & 2.89 & 3.85 & 3.16 & 3.21 & 3.05 \\
\hline Mesodorylaimus & $\mathrm{O}$ & 1.42 & 0.88 & 0.72 & 1.53 & 0.66 & 0.82 & 1.01 \\
\hline Oxydirus & $\mathrm{O}$ & 0.10 & 0.10 & 0.22 & 0.06 & 0.35 & 0.13 & 0.16 \\
\hline Steinernema & IN & 0.47 & 0.16 & 0.17 & 0.22 & 0.38 & 0.25 & 0.27 \\
\hline
\end{tabular}




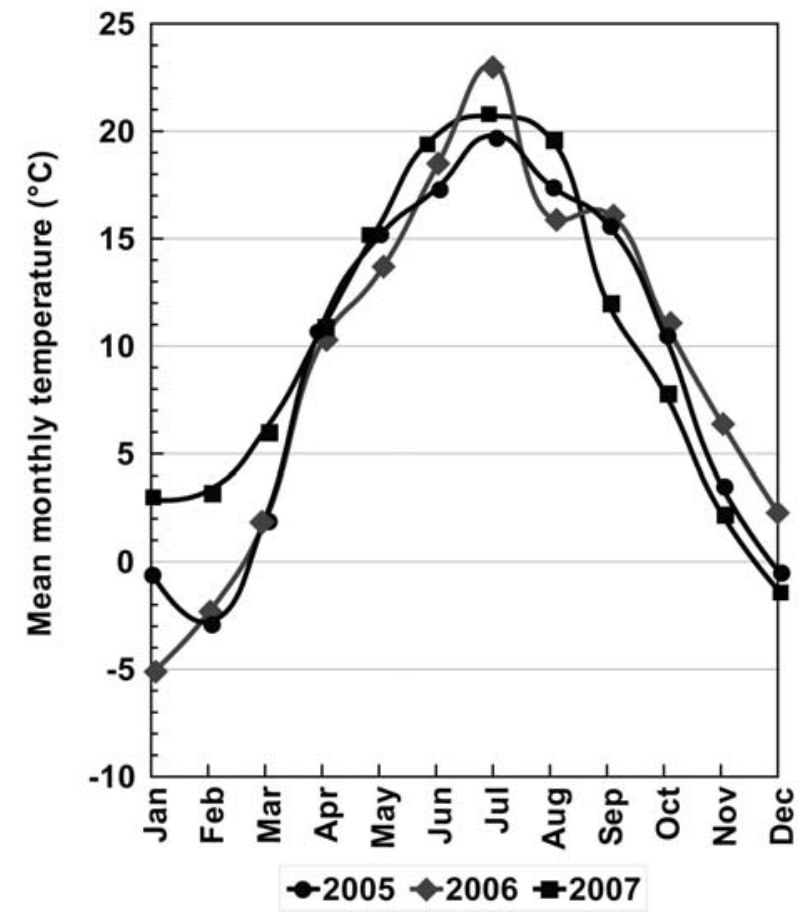

Fig. 1 Mean monthly temperature recorded from January to December in the years 2005, 2006 and 2007

The study was conducted during tree vegetation periods from 2005 to 2007. From May to October, soil samples were collected monthly from the rhizosphere of hop plants at depths of 20 and $40 \mathrm{~cm}$. Nematodes were isolated from $500 \mathrm{~g}$ of mixed soil by using Cobb's flotation-sieving method (Cobb, 1918), fixed in FAA (80 parts distilled water, 16 parts $96 \%$ ethanol, 2.4 parts formalin, 1.6 parts acetic acid) (Johansen, 1940) and identified to genus level. The nematodes were evaluated by dominance of individual genera within sampling dates at the two soil depths. It was calculated as proportion of number of specimens of individual genera and a total number of specimens in soil sample. Results are presented in Table $1-2$. The nematode genera were eudominant at $\mathrm{D}>10 \%$, dominant at $\mathrm{D}=5$ $10 \%$, subdominant at $\mathrm{D}=2-5 \%$ (Losos et al., 1984)

For statistical evaluation, the identified genera were allocated into seven trophic groups (TG) according to classification of Yeates et al. (1993); bacterial feeders (BF), fungal feeders $(\mathrm{FF})$, plant feeders $(\mathrm{PP})$, root fungal feeders (RFF), predators $(\mathrm{P})$, omnivores $(\mathrm{O})$ and insect parasites (IN). Data were analysed by analysis of variance (ANOVA) and means compared by Duncan's Multiple Range Test. All statistical analyses were performed using the PlotIT program v.3.2.

\section{Results and Discussion}

A total of 42 nematode genera, including 7 genera of plant parasites were identified during three vegetation periods (Table $1-2$ ). This number of genera is less than that observed by Lišková (1980) in perennial ecosystems of vineyards (Vitis vinifera L.) in Slovakia, but it is similar to that found by Deming et al. (2006) in perennial ecosystems of Caragana microphylla plantation.

The seasonal fluctuation of mean monthly temperature (Fig. 1), monthly precipitation (Fig. 2), and abundance of nematodes showed similarity during the three years. At the $20 \mathrm{~cm}$ soil depth (Fig. 3) nematodes were more abundant in May than in June in each year. In July the nematode abundance increased again and reached maximum in each year because of high occurrence of BF nematodes of the genus Rhabditis. These agree with finding by Venette \& Ferris (1997) who observed an increase of bacteriovorous nematodes at higher temperatures. In August, September and October, the abundance of nematodes decreased while decrease being related to the decrease of temperatures at the end of vegetation period, and to the highest rainfall recorded in August 2005 and 2006 (Fig. 1 - 3).

At a depth of $40 \mathrm{~cm}$ (Figure 4) the seasonal variation in nematode abundance was similar between in 2006 and 2007 , with a decrease of nematode population from May to October, although a moderate increase was observed during the summer months, probably caused by higher temperatures. A different situation was observed in 2005 when nematode abundance increased from May to July and decreased from July to October.

The mean abundance of nematodes at the $20 \mathrm{~cm}$ soil depth was higher than that to $40 \mathrm{~cm}$ (Table 3). Our results agree with Deming et al. (2006) and Zhang et al. (2007) who recorded a gradual decrease of total abundance of nematodes with an increase of soil depth in several ecosystems. A similar gradual reduction of abundance of nematodes with increase of soil depth was also observed in various types of soil (Valocká \& Sabová 1997; Lazarova, 2004).

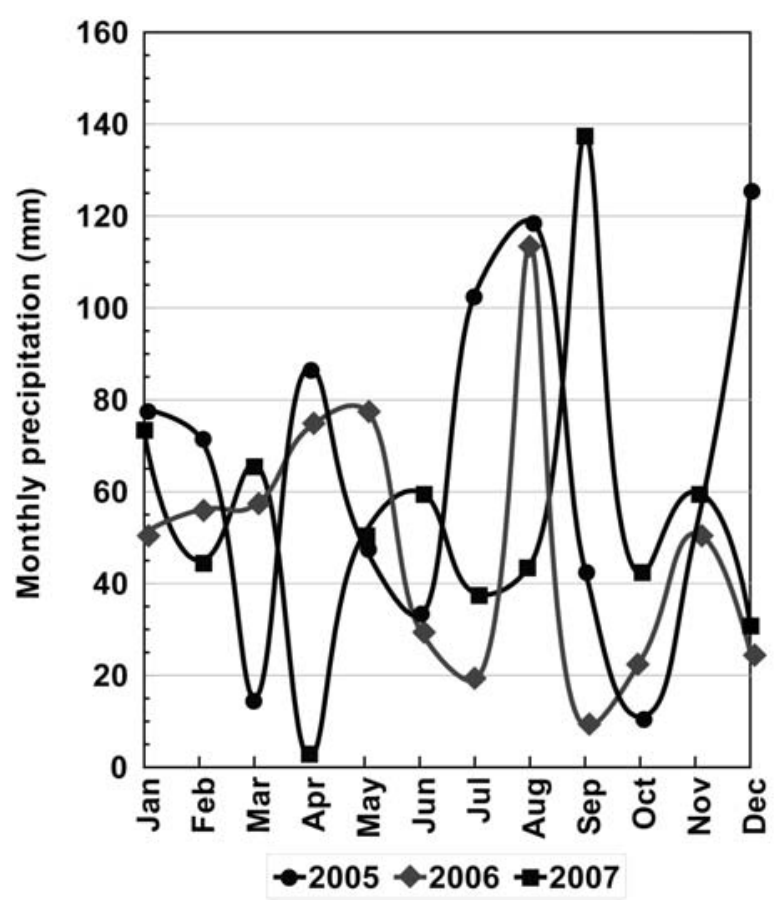

Fig. 2 Monthly precipitation recorded from January to December in the years 2005, 2006 and 2007 
Table 2. Dominance of nematode genera within sampling dates in soil depth of $40 \mathrm{~cm}$

\begin{tabular}{|c|c|c|c|c|c|c|c|c|}
\hline \multirow[t]{2}{*}{ Genus } & \multirow[t]{2}{*}{ TG } & \multicolumn{7}{|c|}{ Dominance $\% \quad(n=3)$} \\
\hline & & $\mathbf{V}$ & VI & VII & VIII & IX & $\mathbf{X}$ & Total \\
\hline Acrobeles & B & 2.47 & 3.49 & 4.6 & 3.61 & 4.4 & 4.28 & 3.73 \\
\hline Alaimus & B & 1.86 & 1.44 & 1.37 & 0.84 & 0.79 & 0.38 & 1.2 \\
\hline Amphidelus & B & 0.35 & 0.46 & - & 0.38 & 0.56 & 0.27 & 0.33 \\
\hline Aulolaimus & $\mathrm{B}$ & 0.13 & 0.03 & - & - & 0.09 & - & 0.05 \\
\hline Cephalobus & $\mathrm{B}$ & 5.94 & 5.74 & 5.74 & 4.79 & 6.48 & 8.56 & 6.07 \\
\hline Eucephalobus & B & 2.83 & 2.77 & 2.34 & 2.58 & 3.43 & 2 & 2.65 \\
\hline Eumohohystera & $\mathrm{B}$ & - & 0.16 & - & 0.52 & 0.19 & 0.38 & 0.21 \\
\hline Chiloplacus & $\mathrm{B}$ & 2.92 & 4.24 & 4.64 & 4.36 & 2.78 & 1.9 & 3.56 \\
\hline Panagrolaimus & B & 1.32 & 2.28 & 1.3 & 0.94 & 1.3 & 1.3 & 1.44 \\
\hline Plectus & $\mathrm{B}$ & 0.9 & 0.91 & 0.9 & 0.38 & 0.88 & 1.25 & 0.84 \\
\hline Rhabditis & B & 17.8 & 16.58 & 16.04 & 19.94 & 15.01 & 15.93 & 16.81 \\
\hline Aphelenchoides & $\mathrm{FF}$ & 1.06 & 0.55 & 1.37 & 1.78 & 2.55 & 1.79 & 1.41 \\
\hline Aphelenchus & $\mathrm{FF}$ & 3.28 & 5.84 & 4.37 & 2.58 & 5.28 & 2.87 & 4.04 \\
\hline Diphtherophora & $\mathrm{FF}$ & 0.16 & - & 0.23 & - & 0.14 & 0.54 & 0.18 \\
\hline Ditylenchus & $\mathrm{FF}$ & 0.06 & - & - & - & 0.09 & - & 0.03 \\
\hline Nothotylenchus & $\mathrm{FF}$ & 1.86 & 1.53 & 1.37 & 4.32 & 3.61 & 1.14 & 2.29 \\
\hline Seinura & $\mathrm{FF}$ & - & 0.1 & - & 0.23 & 0.05 & 0.05 & 0.1 \\
\hline Bitylenchus & PP & 1.35 & 1.24 & 1.56 & 1.22 & 2.55 & 1.41 & 1.52 \\
\hline Helicotylenchus & PP & 13.58 & 11.36 & 10.21 & 4.36 & 7.5 & 6.77 & 9.47 \\
\hline Heterodera & PP & 9.89 & 6.72 & 7.34 & 8.63 & 5.42 & 3.74 & 7.28 \\
\hline Merlinius & PP & 12.72 & 13.54 & 13.81 & 9.29 & 11.58 & 9.32 & 12 \\
\hline Paratylenchus & PP & 3.47 & 2.15 & 2.84 & 3.52 & 2.22 & 4.5 & 3.12 \\
\hline Pratylenchus & PP & 1.54 & 1.73 & 1.5 & 4.27 & 2.32 & 4.12 & 2.44 \\
\hline Tylenchorhynchus & PP & 0.19 & 0.82 & 0.83 & 2.39 & 1.81 & 1.08 & 1.08 \\
\hline Aglenchus & RFF & 0.35 & - & 0.03 & 0.09 & 0.09 & 0.16 & 0.12 \\
\hline Boleodorus & RFF & 1.09 & 1.7 & 0.63 & 2.82 & 1.25 & 1.25 & 1.4 \\
\hline Filenchus & RFF & 0.29 & 0.49 & 0.47 & 0.84 & 0.09 & 0.49 & 0.41 \\
\hline Tylenchus & RFF & 1.8 & 1.44 & 2.94 & 2.06 & 1.2 & 1.73 & 1.85 \\
\hline Campydora & $\mathrm{P}$ & 0.1 & - & 0.07 & - & 0.37 & 0.16 & 0.14 \\
\hline Clarkus & $\mathrm{P}$ & 0.45 & 0.39 & 0.7 & 0.44 & 1.61 & 1.39 & 0.75 \\
\hline Mononchus & $\mathrm{P}$ & 0.29 & 0.42 & 0.43 & 0.89 & 0.28 & 2.28 & 0.78 \\
\hline Mylonchulus & $\mathrm{P}$ & 0.64 & 0.69 & 1.23 & 0.84 & 1.07 & 1.03 & 0.9 \\
\hline Nygolaimus & $\mathrm{P}$ & 0.06 & 0.1 & - & 0.14 & 0.28 & - & 0.09 \\
\hline Tripyla & $\mathrm{P}$ & 0.55 & 0.62 & 0.4 & 0.47 & 0.51 & 0.7 & 0.53 \\
\hline Aporcelaimellus & $\mathrm{O}$ & 2.92 & 3.46 & 4.54 & 3.43 & 4.12 & 7.8 & 4.16 \\
\hline Axonchium & $\mathrm{O}$ & - & 0.07 & 0.23 & 0.09 & 0.26 & 0.49 & 0.15 \\
\hline Dorylaimoides & $\mathrm{O}$ & 0.32 & 0.29 & 0.33 & 0.38 & 0.14 & 0.11 & 0.25 \\
\hline Ecumenicus & $\mathrm{O}$ & 1.38 & 1.04 & 1.3 & 2.26 & 1.99 & 3.25 & 1.67 \\
\hline Eudorylaimus & $\mathrm{O}$ & 3.18 & 4.11 & 2.84 & 2.58 & 4.51 & 4.28 & 3.61 \\
\hline Mesodorylaimus & $\mathrm{O}$ & 0.58 & 1.01 & 1.07 & 0.8 & 0.79 & 0.7 & 0.83 \\
\hline Oxydirus & $\mathrm{O}$ & 0.1 & 0.23 & 0.13 & 0.47 & 0.09 & - & 0.17 \\
\hline Steinernema & IN & 0.22 & 0.26 & 0.3 & 0.47 & 0.32 & 0.6 & 0.34 \\
\hline
\end{tabular}




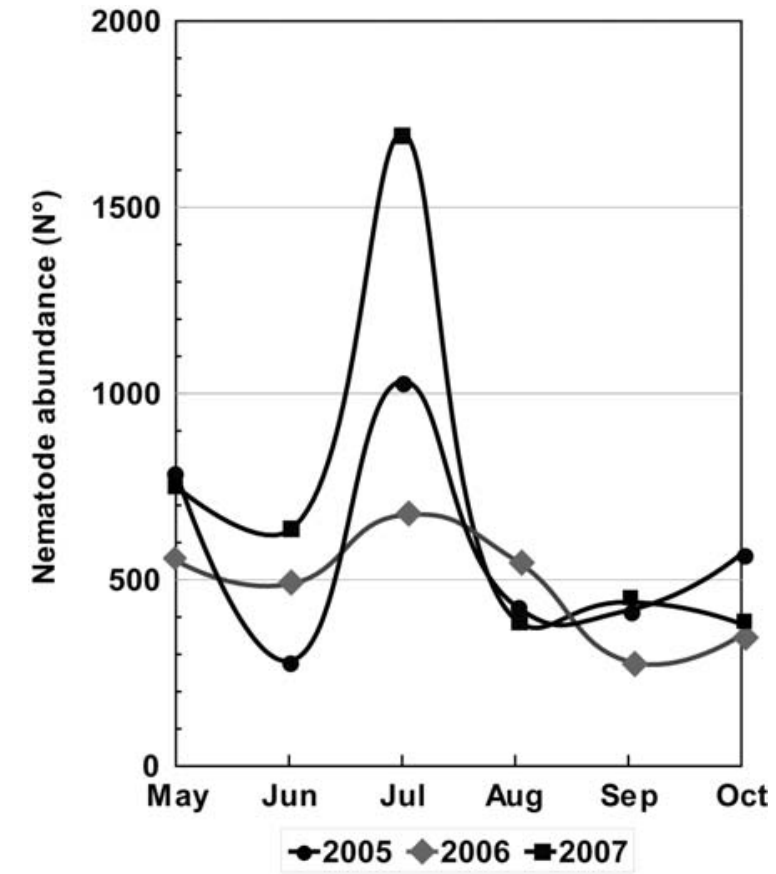

Fig. 3 Nematode abundance from May to October in the years 2005, 2006 and 2007 at $20 \mathrm{~cm}$ soil depth

However, the total number of nematodes was larger in soil with perennial undisturbed natural pasture (Valocká \& Sabová, 1997) or grass and lucerne stands (Sohlenius et al., 1987) than in our hop gardens, characterized by perennial plants with a high level of disturbance agricultural practices such as tillage, cultivation and organic fertilization.

At $20 \mathrm{~cm}$ soil depth, the highest percentage of nematode was represented by BF followed by PP, RFF, O, FF, P and IN (Table 4). These findings agree with previous reports from Slovakian hop gardens (Lišková \& Renčo, 2007) and are similar to those from sugar beet and cereals grown after sugar beet (Renčo 2003, 2004). However, in a study by Deming et al. (2006), the order of abundance of the trophic group was $\mathrm{BF}, \mathrm{O}, \mathrm{P}, \mathrm{PP}$ and $\mathrm{FF}$.

The trophic groups BF (Table 4) prevailed at the $20 \mathrm{~cm}$ soil depth in each sampling dates and it reached greater percentages during August, September and October. However, no significant difference in the proportions of $\mathrm{BF}$ within sampling dates, during three vegetation periods, was found $(\mathrm{P} \leq 0.05)$.

For PP, the second largest trophic group, a significant larger proportion was observed in May and June than in August, September and October, caused by high abun-

Table 3. Mean nematode abundance withing different sampling dates

\begin{tabular}{lcccccc}
\hline \multirow{2}{*}{$\begin{array}{l}\text { Nematode } \\
\text { abundance }\end{array}$} & \multicolumn{6}{c}{ Month of investigation } \\
\cline { 2 - 7 } & V & VI & VII & VIII & IX & X \\
\hline $20 \mathrm{~cm}$ & 698 & 467 & 1135 & 459 & 380 & 434 \\
$40 \mathrm{~cm}$ & 540 & 442 & 462 & 416 & 303 & 276 \\
\hline
\end{tabular}

dance of juveniles and males of the species Heterodera humuli. The occurrence of this species in different Slovakian hop gardens was reported in a previous study (Lišková \& Renčo, 2007). No significant differences were found $(\mathrm{P} \leq 0.05)$ among the percentages of PP recorded in May, June and July, thus confirming findings by Sabová et al. (1987) in cereal monocultures. Higher soil humidity in spring months in addition to new root flushes are favourable conditions for reproduction and invasion of plant parasitic nematodes. On the contrary, climatic conditions in summer months were characterized by lack rainfall and dried soil, which caused a decrease of plant parasitic nematode abundance. $\mathrm{BF}$ and $\mathrm{PP}$ nematodes together represented $69-77 \%$ on total nematode abundance.

Of RFF a significant larger proportion was observed in September than in August (Table 4) with no statistical differences among different months. The FF reached a stable proportion and no significant differences were observed during individual sampling dates. For $\mathrm{P}$ and $\mathrm{O}$ trophic groups a significant smaller proportion was recorded in May than in September and August (Table 4).

At $40 \mathrm{~cm}$ soil depth, with fewer disturbances, the PP group prevailed and it was followed by $\mathrm{O}, \mathrm{RFF}, \mathrm{FF}, \mathrm{P}$ and IN. Moreover, PP prevailed over BF in May, June, July and September sampling dates (Table 4). Maximum proportion of PP occurred in May and June and then decreased throughout October but there were no statistical differences among sampling dates $(\mathrm{P} \leq 0.05)$.

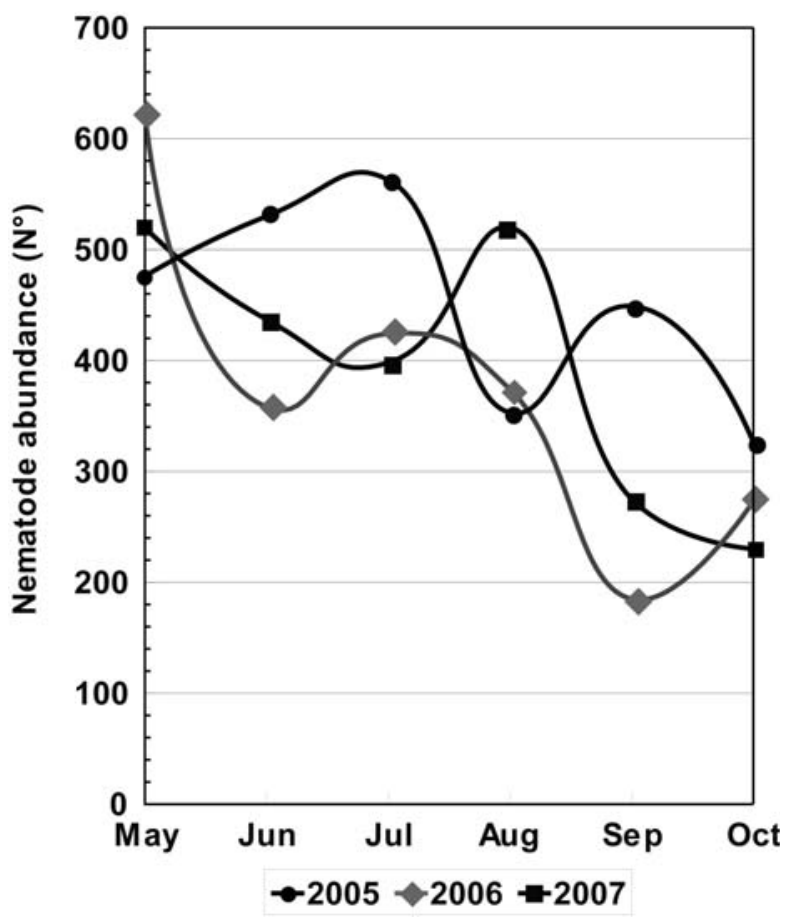

Fig. 4 Nematode abundance from May to October in the years 2005, 2006 and 2007 at $40 \mathrm{~cm}$ soil depth 
BF was the second largest group with its maximum population density reached in August. However, no statistical differences in $\mathrm{BF}$ proportion were found $(\mathrm{P} \leq 0.05)$ during the three vegetation periods (Table 4).

For FF a significant smaller proportion was observed in May and October in comparison to September and no significant differences were found among other sampling dates $(\mathrm{P} \leq 0.05)$ (Table 4). Similarly, a significant lower proportion in May and June, in comparison to October, was found for $\mathrm{P}$ trophic group. of $\mathrm{BF}$, especially in the top $20 \mathrm{~cm}$ soil layer, regularly ploughed and fertilized by organic matter. The higher abundance of BF was also observed at the depth of $40 \mathrm{~cm}$, although at this soil depth the PP slightly prevailed. The increasing number of BF after application of organic material into the soil was also observed by Liang et al. (2001) and Nahar et al. (2006) and also by Renčo (2003) in sugar beet fields where soil was regularly ploughed and amended with organic materials. The larger proportion of BF at 20 $\mathrm{cm}$ soil depth would indicate that nematodes of this trophic

Table 4. Proportion of nematode trophic group (\%) in soil depth of 20 and $40 \mathrm{~cm}$

\begin{tabular}{|c|c|c|c|c|c|c|c|c|c|c|c|c|c|}
\hline \multirow[t]{3}{*}{ Soil depth } & \multirow{3}{*}{$\begin{array}{c}\begin{array}{c}\text { Trophic } \\
\text { group }\end{array} \\
\mathrm{BF}\end{array}$} & \multicolumn{12}{|c|}{ Month of investigation } \\
\hline & & \multicolumn{2}{|c|}{$\mathbf{V}$} & \multicolumn{2}{|c|}{ VI } & \multicolumn{2}{|c|}{ VII } & \multicolumn{2}{|c|}{ VIII } & \multicolumn{2}{|c|}{ IX } & \multicolumn{2}{|c|}{$\mathbf{X}$} \\
\hline & & $42.9 *$ & $a^{* *}$ & 42.3 & $\mathrm{a}$ & 47.3 & $\mathrm{a}$ & 50.3 & $\mathrm{a}$ & 47.9 & $\mathrm{a}$ & 53.1 & $\mathrm{a}$ \\
\hline \multirow{6}{*}{$20 \mathrm{~cm}$} & $\mathrm{FF}$ & 6.3 & $\mathrm{a}$ & 6.4 & $\mathrm{a}$ & 6.8 & $\mathrm{a}$ & 6.4 & $\mathrm{a}$ & 5.7 & $\mathrm{a}$ & 6.1 & $\mathrm{a}$ \\
\hline & PP & 32.0 & $\mathrm{a}$ & 27.8 & $\mathrm{a}$ & 23.8 & $a b$ & 18.6 & $\mathrm{~b}$ & 19.6 & $\mathrm{~b}$ & 18.0 & $\mathrm{~b}$ \\
\hline & RFF & 9.1 & $\mathrm{ab}$ & 10.5 & $\mathrm{ab}$ & 11.9 & $a b$ & 8.4 & $\mathrm{a}$ & 13.3 & $\mathrm{~b}$ & 9.5 & $a b$ \\
\hline & $\mathrm{P}$ & 1.3 & $\mathrm{a}$ & 2.6 & $a b$ & 2.1 & $a b$ & 2.5 & $\mathrm{ab}$ & 3.8 & $\mathrm{~b}$ & 3.0 & $a b$ \\
\hline & $\mathrm{O}$ & 7.7 & $\mathrm{a}$ & 10.0 & $a b$ & 8.8 & $a b$ & 13.2 & $\mathrm{~b}$ & 9.5 & $a b$ & 9.9 & $a b$ \\
\hline & IN & 0.5 & $\mathrm{a}$ & 0.2 & $\mathrm{a}$ & 0.2 & $\mathrm{a}$ & 0.2 & $\mathrm{a}$ & 0.4 & $\mathrm{a}$ & 0.3 & $\mathrm{a}$ \\
\hline \multirow{7}{*}{$40 \mathrm{~cm}$} & $\mathrm{BF}$ & 34.0 & $\mathrm{a}$ & 35.4 & $\mathrm{a}$ & 33.7 & $\mathrm{a}$ & 35.6 & $\mathrm{a}$ & 29.3 & $\mathrm{a}$ & 29.8 & $\mathrm{a}$ \\
\hline & $\mathrm{FF}$ & 6.5 & $\mathrm{a}$ & 8.0 & $a b$ & 7.3 & $a b$ & 8.3 & $a b$ & 11.6 & $\mathrm{~b}$ & 6.7 & $\mathrm{a}$ \\
\hline & PP & 40.3 & $\mathrm{a}$ & 36.3 & $\mathrm{a}$ & 35.8 & $\mathrm{a}$ & 31.4 & $\mathrm{a}$ & 33.0 & $\mathrm{a}$ & 28.7 & $\mathrm{a}$ \\
\hline & RFF & 6.5 & $\mathrm{a}$ & 7.3 & $\mathrm{a}$ & 9.3 & $\mathrm{a}$ & 10.8 & $\mathrm{a}$ & 7.4 & $\mathrm{a}$ & 9.5 & $\mathrm{a}$ \\
\hline & $\mathrm{P}$ & 2.2 & $\mathrm{a}$ & 2.0 & $\mathrm{a}$ & 3.1 & $a b$ & 3.1 & $a b$ & 4.2 & $a b$ & 5.6 & $\mathrm{~b}$ \\
\hline & $\mathrm{O}$ & 9.7 & $\mathrm{a}$ & 10.5 & $\mathrm{a}$ & 10.6 & $\mathrm{a}$ & 10.5 & $\mathrm{a}$ & 13.5 & $a b$ & 17.5 & $\mathrm{~b}$ \\
\hline & IN & 0.4 & $\mathrm{a}$ & 0.5 & $\mathrm{a}$ & 0.4 & $\mathrm{a}$ & 0.3 & $\mathrm{a}$ & 0.5 & $\mathrm{a}$ & 0.8 & $\mathrm{a}$ \\
\hline
\end{tabular}

* Each data is proportion of nematode trophic group on total nematode fauna

** Data flanked in each row by the same letters are not statistically different according to Duncan's Multiple Range Test ( $\mathrm{P}=0.05)$

$\mathrm{BF}$ - bacterial feeders; F- fungal feeders; PP - plant parasite; RFF - root fungal feeders; $\mathrm{P}$ - predators; $\mathrm{O}$ - omnivores; IN - insect parasite

A significant larger proportion of $\mathrm{O}$ trophic group was observed in October in comparison to May, June, July and August, with an increasing tendency from May to October. A similar nematode community structure was recorded by Lišková and Čerevková (2005) in river banks and adjacent meadows, natural ecosystems in Slovak Republic. Freckman and Ettema (1993) recorded, that omnivorous nematodes are very sensitive to agricultural practices. As found by Dabur and Bajaj (2002), populations of omnivorous were significantly larger in non-ploughed than in conventionally ploughed fields. Sánchez-Moreno et al. (2006) recorded, that Discolaimus, Prionchulus, Mylonchulus and Aporcelaimidae were more abundant in intermittent fallow plots and in deeper soil layers. Similarly, López-Fando \& Bello (1995) found that omnivores and predators had greater abundance and diversity in virgin ecosystems than in tilled soil. Althought Gupta and Kumar (1998) and Okada and Harada (2007) observed the stimulation of predators by soil organic amendments, in our study the predators represented a small and stable proportion of nematode communities at both soil depths.

This evaluation of nematode trophic structure showed that community of nematodes in hop garden at Nemšová is rich group contribute to decomposition of cattle manure. This is confirmed by the prevalence of PP on BF in soil with cereals without organic amendment reported by Valocká et al. (2001) and Renčo $(2003,2004)$, and also in soybean fields (Gomes et al., 2003). A similar situation was recorded in ecosystems of vineyards in Austria, in which PP nematodes prevailed, followed by BF, F, O, P and IN (Hoschitz, 2004).

In our hop gardens BF were characterized by prevalence of genera Rhabditis, Cephalobus, Eucephalobus and Chiloplacus, PP by prevalence of genera Heterodera, Helicotylenchus, Merlinius and Paratylenchus (Table 1, 2). The other trophic groups were mainly represented by the genera Aphelenchus and Nothotylenchus (FF); Aglenchus and Tylenchus (RFF); Aporcelaimellus and Eudorylaimus (O). This situation was similar to that found by Renčo \& Valocká (2002), Renčo (2004) and Liang et al. (2001) in soil with sugar beet plants; in rhizosphere of cereals grown after sugar beet or peanut fields. The genera Rhabditis, Cephalobus, Heterodera, Merlinius and Aglenchus at 20 cm soil depth and Rhabditis, Cephalobus, Helicotylenchus, Heterodera and Merlinius at $40 \mathrm{~cm}$ soil depth participated to 50 and $52 \%$ on total nematode abundance, respectively. 


\section{Acknowledgement}

This study was supported by the VEGA scientific grant agency, grant No. 2/7191/27 and Slovak Research and Development Agency APVV, project No. 51-014604.

\section{References}

BAKONYI, G., NAGY, P. (2000): Temperatures-and moisture-induced changes in the structure of the nematode fauna of a semiarid grassland -patterns and mechanism. Glob. Change Biol., 6: 697 - 707

CoBB, N. A. (1918): Estimating the nema population of the soil. Agric. Tech. Circ. Bur. Pl. Ind. U.S. Dep. Agric., 1

DABUR, K. R., BAJAJ, H. K. (2002): Nematode trophic groups as affected by zero-tillage in rice-wheat cropping system. In: Singh, R. V., PANKAJ, DHAwAN, S. C., GAUR, H. S. (Eds) Proceedings of National Symposium on Biodiversity and Management of Nematodes in Cropping Systems for Sustainable Agriculture, Jaipur, India, 11 - 13 November, 2002, Pp. $81-84$

Deming, J., QI, L., Fangming, L., Yong, J., Wenju, L. (2006): Vertical distribution of soil nematodes in an age sequence of Caragana microphylla plantations in the Horqin Sandy Land, Northeast China. Ecol Res., 22: 49 56

Freckman, D. W., EtTemA, C. H. (1993): Assessing nematode communities in agroecosystems of varying human intervention. Agric. Ecosys. Environ., 43: 239-261. DOI: 10.1016/0167-8809(93)90074-Y

Gomes, G. S, HuAnG, S. P., CARES, J. E. (2003): Nematode community, trophic structure and population fluctuation in soybean fields. Fitopatol. Bras., 28: 258 - 266. DOI: 10.1590/S0100-41582003000300006

GuptA, M. C., KuMAR, S. (1998): Influence of certain organic amendments on the population dynamics of predatory nematodes, Mononchus papillatus and Dorylaimus bastiani in soil. Ann. Plant Protec Sci., 6: 48 - 52

Hay, F., Pethybridge, S. (2003): Plant-Parasitic Nematodes Associated with Hop Production in Tasmania, Australia. J. Phytopathol., 151: $369-375$

Hoschitz, M. (2004): Community and trophic structure of soil nematodes associated with Vitis spp. in Austria. Verhandlungen der Zoologisch-Botanischen Gesellschaft in Österreich 141: 97 - 107

Johansen, D. A. (1940): Plant microtechnique. New York \& London, McGrow Hill Book Co.

Lazarova, S. S., de Goede, R. G. M., Peneva, V. K., Bongers, T. (2004): Spatial patterns of variation in the composition and structure of nematode communities in relation to different microhabitats: a case study of Quercus dolechampii Ten forest. Soil Biol. Biochem., 36: 710 - 712 Liang, W. J., LAVian, I., Steinberger, Y. (2001): Effect of Agricultural Management on Nematode Communities in a Mediterranean Agroecosystem. J. Nematol., 33: 208 213

LiAnG, W. J., Li, F. P., QI, L., Zhang, W. D. (2007): Temporal dynamics of soil nematode community structure under invasive Ambrosia trifida and native Chenopodium serotinum. Helminthologia, 44: 29 - 33. DOI: 10.2478/s11687-006-0053-6

LIŠKOVÁ, M. (1980): Nematodofauna of the rhisosphere of Vitis vinifera L. in East-Slovakia. Biologia Bratislava, 35: $357-366$

LiŠKOVÁ, M., ČEREVKOVÁ, A. (2005): Nematode communities of river banks and adjacent meadows in the Slovak Republic. Helminthologia, 42: 223 - 232

LIŠKOVÁ, M., RENČO, M. (2007): Communities of free living and plant parasitic nematodes in hop gardens in Slovakia. Helminthologia, 44: $80-86$. DOI: 10.2478/s11687-007-0008-6

LóPEZ-FANDO, C., BELlo, A. (1995): Variability in soil nematode populations due to tillage and crop rotation in semi-arid Mediterranean agrosystems. Soil Till. Res., 36: $59-72$

Losos, B., GuličKA, J., LelláK, J., PelikÁN, J. (1984): Animal Ecology. Státní pedagogické nakladatelství Praha, 316 pp. (In Czech)

Nahar, M. S., Grewal, P. S., Miller, S. A., Stinner, D., Stinner, B. R., Kleinhenz, M. D., Wszelaki, A., DoOHAN, D. (2006): Differential effects of raw and composted manure on nematode community, and its indicative value for soil microbial, physical and chemical properties. Appl. Soil Ecol., 34: 140 - 151. DOI: 10.1016/j.apsoil.2006.03.011

Neher, D. A., Wu, J., Barbercheck, M. E., Anas, O. (2004): Ecosystem type affects interpretation of soil nematode community measures. Appl. Soil Ecol., 30: 47 64. DOI:10.1016/j.apsoil.2005.01.002

OKADA, H., HARADA, H. (2007): Effect of tillage and fertilizers on nematode communities in a Japanese soybean field. Appl. Soil Ecol., 35: 582 - 598. DOI: 10.1016/j.apsoil.2006.09.008

RENČO, M. (2002): Seasonal dynamics of plant parasitic and free living nematodes in sugar beet, cereals and lucerne fields in East Slovakia. Helminthologia, 39: 51 - 57 RENČO, M. (2003): The communities of nematodes in agroecosystems of sugar beet, cereals and lucerne in Eastern Slovakia. Helminthologia, 40: 55 - 58

RENČO, M. (2004): Communities of nematodes in cereal fields following sugar beet. Helminthologia, 41: $109-112$ RENČO, M., VALOCKÁ, B. (2002): Communities of soil and plant nematodes in sugar beet growing areas of the Slovak Republic. Biologia, Bratislava, 57: $569-573$

SABOVÁ, M., LIŠKOVÁ, M., VALOCKÁ, B. (1987): Seasonal dynamics of parasitic nematodes in cereal monocultures and under crop rotation in relation to climatic and soil conditions. Biologia, Bratislava, 42: 121 - 126

SÁnCHEZ-MORENO, S., MinOSHIMA, H., FERris, H., JACKSON, L.E. (2006): Linking soil properties and nematode community composition: effect of soil management on soil food webs. Nematology, 8: 703 - 715. DOI: $10.1163 / 156854106778877857$

Sohlenius, B., Boström, S., SANDOR, A. (1987): Longterm dynamics of nematode communities in arable soil under four cropping systems. J. Appl. Ecol., 24: 131 - 144 
VAlockÁ, B., SABovÁ, M. (1997): Communities of soil and plant nematodes in two types of grass land. Helminthologia, 34: $97-103$

VAlockÁ, B., SABovÁ, M., RenČo M. (2001): Soil and plant nematode communities of two types of ecosystems. Helminthologia, 38: 105 - 109

VenetTE, R. C., Ferris, H. (1997): Thermal constraints to population growth of bacterial-feeding nematodes. Soil Biol. Biochem. 29: 63 - 74. DOI: 10.1016/S0038-

RECEIVED JUNE 29, 2009
0717(96)00259-3

Zhang, X. K., Liang, W. J., JiAng, D. M., LiU, Z. M., JIANG, S. W. (2007): Soil nematode community structure in a Chinese sand dune system. Helminthologia, 44: $204-$ 209. DOI: $10.2478 / \mathrm{s} 11687-007-0032-6$

Yeates, G. W., Bongers, T., De Goede, R. G. M., FreckMAN, D. W., GEORGRIEVA, S. S. (1993): Feeding habits in soil nematode families and genera - An outline for soil ecologists. J. Nematol., 25: $315-331$ 